\title{
Culture Problems in English Teaching of Non-English Majors
}

\author{
Liyan $\mathrm{He}$ \\ Foreign Language Department. \\ Langfang Teacher's College, \\ Langfang City, Hebei Province, China \\ Liyanhe619@163.com
}

\begin{abstract}
The article discusses cultural differences between different ethnic groups, as well as the importance of cultural education in college English teaching and communicative competence. The article starts from teaching practice. It points out some cultural and educational countermeasures for students.
\end{abstract}

\section{Keywords-cultural education; cultural differences; communicative competence}

\section{INTRODUCTION}

Language is one of the socio-cultural factors, which is the carrier of culture. The contents of culture can be reflected through language. Different nationalities have different geographical locations, history, ways of thinking, habits, values and religious beliefs. Thus it creates different cultural norms. Culture teaches people how to use the language. And some languages, only in specific cultural contexts, produce the associated language communicative sense. Language cannot be separated from culture, while culture relies on language. Now that the English teaching is language teaching, it is inseparable from culture and education. [1]

\section{RESEASONS OF CULTURAL EDUCATION}

\section{A. Cultural Differences are Obstacles to Cross-Culture Communication.}

The process of modernization speeds up the flow of spiritual and material goods, which brings various ethnic groups into a "global village". The intercultural communication becomes an integral part of the life of each people. However, cultural differences are the barriers in cross-cultural communication. The communication barriers that cause by overcoming cultural differences have become a world-wide common problem. In China, the "Dragon (Dragon)" is our spirit Totem, which is a symbol of power and good fortune. The Chinese are so proud of "descendants of the Dragon". In Chinese, "Dragon" is always used for good. However, in Western cultures, the Dragon represents evil, drawing from "vicious cruelty" (tierce person), "sly, hypocritical" (shy or treacherous person), the old dragon has become the synonym of the devil.

\section{B. Cultural Education is the Key to Communication that Make Use of Language.}

The ultimate aim of English teaching is to develop communicative competence. Language skills are the foundation of communicative competence. However, the language ability that students possess does not mean that they have the communication skills. More and more people have reached an agreement, which communicative competence includes four language skills (listening, speaking, reading and writing) and socio-cultural competence (that is, harmonious communication with people from different cultural backgrounds). Current college English teaching, however, due to the influence of traditional methods, teachers ' and students ' energies were poured on the language form, and ignored the social context of language, particularly the linguistic and cultural differences. The common weakness of the majority of college graduates is that they know little about British and American culture based on some non-linguistic cultural background and social norms. So they are not good at intercultural communication. That it is to say, they pay much attention to language learning. They neglect the language use in real-world situations, ignoring the differences between Eastern and Western culture. They are very familiar with Chinese "san jiu" "san fu", which means the hottest and coldest days of one year, but how to represent them accuratly in British and American culture is not clear. Practice has proved that the cultural factor teaching should become an important part of college English teaching.

\section{THE SPECIFIC PERFORMANCE OF CULTURAL DIFFERENCES}

\section{A. Cultural Implications of Vocabulary}

Language learning process is also the process of accumulation cultural knowledge. Different languages reflect different cultural differences, which can be found in the unique culture of the nation's vocabulary. English words in long term use has accumulated a wealth of culture, teaching should pay attention to the introduction of the cultural significance of vocabulary to prevent students from a purely subjective assessment of the vocabulary itself. Words "red", either in English or in China, it is often associated with celebrations or festival days. There are "red-letter days" in the English language (excluding public holidays). Especially in China, the Red symbolizes the revolution and socialism, but in English 
"red" also means danger or annoy, such as "red flag" (inductive mad thing). Also when we see "in the Red" in business English, it doesn't mean that was profitable, and instead, losses and liabilities. [2]

\section{B. The Pragmatic Appropriateness}

- When people are communicating, words can't be isolated. Both participants must be able to properly use a coherent discourse. In terms of words, some words between Chinese sounds very proper, but for British people, they sound out of place, harsh, or even misleading. For example someone thank you, Chinese used to say, "This is what I should have done", a literal translation into English is "It is my duty. I ought to do that." British people may not be happy. Because he thought your help is not by intention. It should be translated "You are welcome. It is a pleasure. Not at all." which is the properest translation. In general, we Chinese are rarely use "thank you" between family members. If you use one, it sounds strange. In Englishspeaking countries, "Thank you." is an expression that can be used for almost every occasion. All human beings, even if parents and children, brothers and sisters are no exception. If someone sends a bottle of drink, prepares a meal, the other side will say, "Thank you." Regardless of what others do for you in public, you're with a "Thank you." This is the most basic etiquette.

\section{Taboo}

People are not allowed to say certain words, do certain things and to use certain utensils because of ignorance, superstition, or socio-cultural needs. "13" and "Friday" considered a symbol of the dangers are taboos in Britain, the United States and other Western countries. That will bring disaster to the people. Therefore, people have tried to avoid the two numbers. For instance, the hotels do not have 13 floors and not 13 as a room number. People do not have a trip on the 13th and so on. [3] Age, to most British and Americans, is one of the things considered improper to ask a stranger or a person that one does not know well. Besides age, other such matters include one's income, martital status, politics and religion. Some people may not mind and will readily talk about such things, but it is not polite to ask unless the other person shows that he/she will not be offended. Thus questions like the following, although inoffensive to Chinese, should be avoided when conversing with English-speaking people: Where are you going? What are you doing? How old are you? Wha's your income?

\section{Holiday}

Cultural differences between Chinese and English-speaking countries are obvious in the aspect of festival. Apart from the common festivals (such as the New Year's Day), the two sides also have their own unique festival. In China, there are the Spring Festival, the Dragon Festival, and Mid-Autumn Day; In western countries, they have the following festivals, such as Valentine's Day, Easter, April Fool's Day, the Mother's Day, Thanks Giving Day and Christmas Day and so on. Western holidays and customs are not the same. During the holidays, people give gifts, China and English-speaking countries also show a different attitude. Chinese people often pretend and helplessly accept. Even if they accept the gifts, they don't open it face to face. If they open it face to face and show that they love it, they're afraid to leave an impression of "greedy" on the others. In the culture of English, people send gifts to the others. They generally have to open it face to face and gladly give thanks.

- And in writing the envelope address, it also represents different aspects of cultural differences. As for some problems, Chinese people like to think about them from the general to the particular while British focus more on the individual. When Chinese people write letters, they usually write address on the envelope from large to small, house number and the recipient, while English is exactly the opposite, from small to large. When students write letter, they usually make a mistake that they write the date at the end of the letter. These are caused by the Sino-British cultural differences.

\section{Cultivating NON-ENGLiSH MAJOR STUDENTS' CULTURAL AWARENESS}

With the rapid development of science and technology in China, frequent exchanges between the international and intercultural communication are increasing in our country. The demands for talents with cross-cultural communicative competence become more prominent and more urgent. Due to the differences between different cultures, misunderstandings in communication are often happened. A lot of people recognize the importance of cultural education in college English teaching. This requires that teachers should adopt a flexible approach to improve students' sensitivity to the culture, so that they can incorporate actively and consciously into the new culture environment. [4]

\section{A. Enriching Social and Cultural Knowledge of Students}

Many materials of college English in each course involved in the British and American cultural background knowledge, such as geography, history, politics, economy, customs and habits, events, etc. In the process of teaching, teachers should consciously increase and rich cultural knowledge related to British and American. At the same time, teachers should strengthen the cultural differences comparison between Chinese and western countries so that they can easily penetrate the cultural differences into their English teaching, which can help students understand the material better. For example, there is an article called Marriage across Nations in Unit Three of Book Two, New Horizon College English. It tells us about transnational marriage between a black man and a white woman. When they spread the news of their wedding plans to her family, she met with some resistance. Teachers can take this opportunity to introduce western marriage customs, as well as additional information on discrimination some knowledge. 


\section{B. Cultivating Students' Interest in British and American Culture}

With the development of the society, each event may not be isolated. Therefore, teachers should guide students to know consciously and actively about the event and reality that happened in Britain and America in order to achieve a more profound understanding. British and American newspapers and magazines, the original film and Internet are everywhere in our life. British and American culture influence our thinking and living habits. Teachers should try to introduce and comment on them appropriately and guide students independently to obtain information. After a period of practice, students are gradually interested in British and American culture. Through the comparison between Chinese and western culture, they can absorb critically the cultural content beneficial for our social development .

\section{Mobilizing Students' Initiative of Learning English}

For most people, learning English is not a very happy thing. Students often think learning English dull even upset because of their difficulties in pronunciation, spelling errors, small vocabulary and grammar problems. Teachers can collect some articles and pictures of English countries to make students understand the foreign art, history and customs. Students can have the intuitive feeling by using English movies, TV, slide show, video and other information in order to make the student be exposed to the actual use of English. Teachers can recommend some simple reading reflecting the foreign cultures to students so as to increase the understanding of English culture. It is also helpful that inviting the experts who have a good command of Chinese and English make special reports on the cultural differences. Also, creating the language environment of various forms, such as English corner, English party, etc, can deepen the practical application of cultural knowledge so that the students gradually become interested in English and stimulate their learning initiative.

\section{WAYS TO STRENGTHEN CULTURAL EDUCATION}

\section{A. Comparison Method}

Through the comparison between the different cultures, it is possible to find the difference so as to deepen students' understanding and cross-cultural awareness. In the English teaching of non-English major students, it is usually the comparison between British and American culture and Chinese culture. By comparison, students can not only find the differences, but also can be more objective to understand the two cultures and appreciate the two kinds of culture and tradition. At the same time, it is beneficial for students to grasp the thinking structural differences between English and Chinese. It aslo can cultivate the students' cultural creativity. [5] As for students, they learn not only new things of foreign culture, also better explain the traditional national culture in order to improve the ability of cross-cultural communication.

\section{B. Expanding Interpretation Method}

In the English class, it is impossible to systematically introduce the culture of English-speaking countries because of the limited time. So it's a better way to offer some practical selective courses at the college as a supplement to college English teaching and cultural knowledge, such as, An Introduction to Britain and America, British and American Film Appreciation, British and American Music Appreciation and Cross-cultural Communication Introductory courses. They can effectively increase the students' knowledge of British and American culture, effectively improve the ability of crosscultural communication.

\section{Extracurricular Learning Method}

British and American culture learning outside the classroom, that is, the second classroom is achievable. First of all, it's helpful to organize the seminar of Chinese and foreign teachers. They will introduce in-depth some content. Second, it's useful to offer special English corner, invite British and American teachers and students to attend. They hold discussion based on the given topic. Through the face-to-face communication, students can study the cultural knowledge. Finally, it's essential to improve students' cultural awareness and sensitivity during the life, such as watching English movies, reading English newspapers, reading social and cultural books about English countries, etc. These methods can cultivate the students' good habits of English learning and enrich students' knowledge. They can benefit from it in the lifetime.

\section{CONCLUSION}

College English teaching is not only teaching language but also teaching culture. When teachers teach language, they will combine cultural background and cultural connotations. On the one hand, they often input some British and American cultural practices for students. On the other hand, they will continue to correct the language of British and American cultural practices that are not irregular. Teachers use a variety of methods and tools to enhance student's intercultural awareness, improve the ability of intercultural communication. Only in this way can students use the language right in practice.

\section{REFERENCES}

[1] Claire Kramsch, Lanfuage and Culture. Shanghai: Shanghai Foreign Language Education Press, 2004

[2] Deng Yanchang and Liu Runqing, Language and Culture. Beijing: Foreign LanguageTeaching and Research Press, 1995

[3] Hu Wenzhong, A Dictionary of British and American Culture. Beijing: Foreign Language Teaching and Research Press, 1997

[4] Zhao Aiguo, Jiang Yaming, An Introduction to Language Cultrrology. Shanghai: Shanghai Foreign Language Education Press, 2003.

[5] Chen Shen, The Teaching of Clutures in Foreign Language Education.

[6] Beijing: Beijing Language and Culture University Press, 1999. 